\title{
IMPLEMENTATION OF BUSINESS
}

\section{PLANNING PROJECT WITH EXPERIENTIAL APPROACH: A CASE STUDY OF ENTREPRENEURSHIP TEACHING TO NON-BUSINESS STUDENTS}

\section{Ignatius Srianta' and Catharina Yayuk Trisnawati}

Widya Mandala Surabaya Catholic University, Indonesia

\begin{abstract}
Business planning project with experiential approach have been implemented in beverage processing technology course, as a part of entrepreneurship teaching in undergraduate food technology study program. Seventy one students were divided into 6 groups and each group designed a business plan of beverage production. The business plans (production of RosBerry juice, Alang-alang jelly drink, Luo Tung Kua healthy drink, Aloe vera juice, Soycorn milk and Bumble bee) were realized by production each product in pilot plant and selling the products in campus area. Five groups succeed to realize their business plans and get profit varies from $11.67 \%$ to $58.29 \%$, but one group (production of Bumble bee) suffered losses of $28.63 \%$. About $84 \%$ of students possess sufficient self-confidence to success as an entrepreneur. Significant increasing of self-confidence to success in business planning and marketing occurred. However, declining of self-confidence also occurred especially in financing and managerial skill aspects. It is needed to improve self-confidence in financing and managerial skill aspects.
\end{abstract}

Keywords: business planning, project, experiential approach, non-business students, food technology, entrepreneurship teaching

\section{INTRODUCTION}

Entrepreneurship is commonly seen as a positive aspect of economic development (Koster and Rai, 2008). According to Global Entrepreneurship Monitoring (GEM), there are three major phases of degree of involvement in entrepreneurial activity within a country are recognized: factor-driven economies, which are primarily extractive in nature, efficiency-driven economies in which scale-in- tensity is a major driver of development, and innovation-driven economies. As countries develop economically, they tend to shift from one phase to the next (Bosma et al, 2009). In Asian developing countries, entrepreneurship development is currently an important issue related to economic development in the countries. It is publicly believed that the lack of entrepreneurship together with limited capital, skill workers and technology have been the main important causes of relatively

${ }^{1}$ Corresponding author: Ignatius Srianta, Department of Food Technology, Faculty of Agricultural Technology, Widya Mandala Surabaya Catholic University, Jl. Dinoyo 42-44 Surabaya, Indonesia 60265, Email: srianta_wm@yahoo.com 
economic backwardness in most of Asian countries. Realizing this, training in entrepreneurship has been included as an important part of government programs to support the development of small and medium enterprises (SMEs) in the Asian developing countries (Tambunan, 2009).

A nationwide survey of entrepreneurship education in South Africa showed that the most respondent, administrators (deans, heads of schools and directors of entrepreneurship centre) and teaching staff of 23 universities (11 "traditional universities", 6 comprehensive universities and 6 universities of technology), acknowledge the importance of entrepreneurship as a subject field in their respective universities. For undergraduate level, 35\% indicated that it is very important, while of $32 \%$ said it was important. For Master level, $19 \%$ perceived it as very important, while $42 \%$ of the academics viewed it as important (Co and Mitchell, 2006). Research into the nature, antecedents and effects of university-level entrepreneurial activities has grown rapidly over the past 25 years (Yusof and Jain, 2010). A Survey towards 332 students from three different universities in three different countries (Indonesia, Japan and Norway) shows that entrepreneurial intentions among the students and the influencing factors differs across countries. Educational background becomes a key factor, which influence entrepreneurial intention among Indonesian students (Indarti and Rostiani, 2008). Most universities offer at least one course in entrepreneurship, primarily through their Business School (Lumsdaine and Binks, 2003).

In response to a recognition that entrepreneurial activity and interest does not occur exclusively among business majors, universities have begun to offer courses and minors in entrepreneurship to non-business majors.
Research has found most entrepreneurs do not graduate with business degree (Kauffman Foundation). A single entrepreneurship course in a student's undergraduate education is probably not sufficient to create a successful entrepreneur, but it can focuses on what entrepreneur do, and does not address the theories that underlie entrepreneur behavior. The course might increase understanding of entrepreneurship, consider entrepreneurship as a career possibility and instill entrepreneurial attitudes that can be used in a variety of life's endeavors (Frazier, 2005). Azizi et al (2010) have conducted an applied research which carried out in a survey way toward 355 students sample of 19255 students population in applied-scientific education in agriculture in Iran, then concluded that entrepreneurial education has a tremendous potential to help in the employment status of students in Iran's applied-scientific educational centers for agriculture. The development of entrepreneurial education results in creating more jobs and employment sustainability could be achieved over time. They also suggested that the institution need to provide practical training in entrepreneurship to their students, to make them more aware of the benefits of entrepreneurship. Frazier (2005) has been successfully implemented an entrepreneurship teaching project in undergraduate program in Family and Consumer Sciences, where students major in dietetics, family studies, food service administration, interior design, and apparel merchandising and design.

Entrepreneurship curricula have been standard in business colleges for decades. Content of entrepreneurship course is varies widely, one of the more popular curricula formats consists of teaching and monitoring the production of a business plan. In a study of leading entrepreneurship educators, the development of a business plan was identified 
as being the most important course feature of entrepreneurship courses. Examining of the 2004 college catalogs of all of the top 100 universities in the United States for courses that specifically referred to business plan education in their course description, it was found 78 of the top universities offered such courses, typically in the area of entrepreneurship or small business management. In general, research findings suggest that exposure to certain types of entrepreneurship education increase individual self-reported intentions to begin a business. In particular, practical programs that provide real-world experience seem particularly useful in enhancing intentionality through increased perceived desirability and feasibility (Honig, 2004). Frazier (2005) reported the success of carrying out a comprehensive project about entrepreneurship to teach non-business students, which the primary learning activity is a business plan project. Student teams develop a business plan for a new venture that could be viable in the central business district located in the university community.

The aim of this entrepreneurship teaching to non-business students was to implement business planning project with experiential approach in beverage processing technology course. Beverage processing technology course is a 2 credits course subject in undergraduate degree curriculum of Food Technology study program, Widya Mandala Surabaya Catholic University (WMCSU), which was offered since 2006.

\section{METHODOLOGY}

\section{Course subject and students}

The project was implemented in beverage processing technology course subject in even semester (January until July 2010) in Department of Food Technology, WMCSU.
Seventy one of students were divided into 2 classes: class A (47 students) and class B (24 students). Each student filled out a questionnaire about parent's occupation, student activity and career planning in the future. Entrepreneurial spirit indicated from student willingness to become an entrepreneur as the future planning after he/she graduated from the undergraduate study.

\section{Teaching method}

The teaching method was a combination of conventional learning in the classroom and implementation of business planning project with experiential approach. Topics of the course are ingredients, processing, packaging, quality control and shelf life of Fruit Juice, Soft Drink, Alcoholic Drink, Bottled Fresh Water, Energy Drink, Sport Drink, Functional Drink and Powder Drink.

Implementation of business planning project was conducted by cooperative experiential approach. Students were divided into several groups (grouping) consisting of 11-12 students each. Each group designed a draft of beverage production business planning through market survey and group discussion. Each group presented their draft of business plant to get input from lecturers and other students. All of students and lecturer visited the beverage industries to learn the beverage production in commercial scale. Then, each group realized the revised business plan through production in pilot plant scale and selling for 2 weeks. After that, all of business plan realizations were presented in an evaluation seminar forum attended by all of students, lecturers and invited beverage entrepreneurs.

\section{Measurement of self-confidence of student}

Self-efficacy of all students were measured 
before and after taken the course (attached questionnaire). Self -confidence consist of self-confidence to be a success entrepreneur, to success on capital and financial aspect, on managerial skill, on business planning and on selling product. Score 1 indicated the lowest self efficacy and 10 for the highest.

\section{FINDINGS AND DISCUSSION}

\section{Student characteristics and entrepreneurship spirit}

Student majority in the beverage processing technology course are female (76.06\%). In generally, student majority in WMCSU are female. They also have a unique characteristic i.e. most of student parent are entrepreneur $(61.97 \%)$. This fact is a reason for WMSCU, including food technology department, concerning on entrepreneurship teaching. Most of students are focus on studying (61.04\%), and $25.35 \%$ of them studying and working independently. Several of them $(8.45 \%)$ are working in the business of their parents. There was no student who working in the company. Most of students have high entrepreneurial spirit which indicated from career planning in the future. Major career planning in the future of the students are entrepreneur $(84.50 \%)$, however most of them $(70.42 \%)$ do not have a sufficient self-confidence to success in building a new venture immediately after graduation, therefore they need working experience in company, and then they will build a new venture.

\section{Business planning, realization and evaluation}

The below table show business planning of each group, its realization and evaluation:

\section{Production of Strawberry-Roselle juice with capacity of 14 L/day}

The group of students created a strawberry-roselle juice with brand name RosBerry juice. They chosen strawberry and roselle because the two materials are rich in anthocyanin which poses antioxidant activity. The non-complicated processing is also a reason to produce the product. The production steps were extracting strawberry and rosella separately, then mixing of the extracts and sugar syrup, then diluting, homogenization, pasteurization $\left(90^{\circ} \mathrm{C}, 10\right.$ minutes), cooling (until $\left.80^{\circ} \mathrm{C}\right)$, bottling (hot filling @330 mL) and labeling. The product has a long shelf life in refrigeration storage because of its natural high acidity. Total production cost, income and profit were IDR 689,775; IDR 1,082,500; and IDR 392,725 (56.94\%), respectively. In evaluation forum, invited entrepreneurs provide a positive comment to the product created by this group. It was a new product in beverage market. They suggested to more careful on the raw materials quality, especially the strawberry since it is a perishable food. In scaling up or mass production, strawberry handling and storage are critical step for loosing its quality.

\section{Production of Alang-alang jelly drink with capacity of 22.5 L/day}

Alang-alang (Imperata cylindrica L.) is a type of grass. Its root is a part containing arundoine, fernenole, isoarborinole, silindrine, simiarenol, kompesterol, stigmasterol,ßsitosterol, skopoletin, skopolin, p-hidroxybenzaldehyde, cathecol, chlorogenic acid, isochlorogenic acid, caumaric acid, malic acid, and flavonoid. It has antipyretic effect, diuretic effect and homeostatic effect. It also contains phenolic substances with antioxidant 
activity. Those facts are the reasons to choose alang-alang as a base material for producing jelly drink. It is very limited type of product made from alang-alang. The unique product was named as Alang-Alang jelly drink. They produced Alang-Alang jelly drink by extracting alang-alang, then mixing of the extract with other ingredients (carrageenan, sodium citrate, sugar and natural flavoring wintermelon) then homogenization, pasteurization $\left(90^{\circ} \mathrm{C}, 10\right.$ minutes), filling (@150 mL) and labeling. Total production cost, income and profit were IDR 260,835; IDR 447,500; and IDR 86,665 (33.23\%), respectively. In evaluation forum, invited entrepreneurs mention the product as a prosperous product. It was a new product in beverage market. However, the raw material is too expensive because they bought it in market which is mix of fresh and not fresh alang-alang. They suggested buy alang-alang from farmer, so that they find a fresh material with low price.

\section{Production of Luo Tung Kua Healthy drink with capacity of 8.5 L/day}

Brand name Luo Tung Kua was obtained from the name of main ingredients i.e. Luo Han Kuo and Tung Kua. Luo Han Kuo have been used traditionally as a nutritious fruit in China because of it contain vitamins $(\mathrm{A}, \mathrm{B}, \mathrm{C}, \mathrm{D}, \mathrm{E})$, carotenoids, phosphorus, iron, calcium, potassium, magnesium and zinc. Tung Kua was chosen for flavoring since it has an interesting aroma. They produced Luo Tung Kua by mixing Luo Han Kuo extract and Tung Kua extract, pasteurization $\left(90^{\circ} \mathrm{C}, 10\right.$ minutes) and filling in cup. The product was served as a fresh drink in cup. Total production cost, income and profit were IDR 240,000; IDR 288,000; and IDR $28,000(11.67 \%)$, respectively. Invited entrepreneurs suggested improving label on the cup, so it will become more attractive. According to the entrepreneurs, students need to create a uniqueness of this product such as by using fresh Tung Kua since they used instant Tung Kua.

\section{Production of Aloe vera juice with capacity of 24 L/day}

Aloe vera (Aloe barbadensis) is a cactus-like plant which growing easily in Indonesia. It is cultivated in many areas of Indonesia. It contains nutrients such as dietary fiber, vitamin and mineral. It also contains bioactive compounds. The group of student argues that aloe vera have a huge potency since it has high productivity and it is a perishable material which need to be processed. They produced a ready to drink aloe vera juice by washing, peeling, cutting aloe gel into small cube, salting (to remove aloin, a bitter compound), washing, blanching (90oC, 3 minutes), draining, crushing and mixing with ingredients: sugar and lemon). The product was served as a fresh drink in cup of $350 \mathrm{~mL}$. Total production cost, income and profit were IDR 217,950; IDR 345,000; and IDR 127,050 (58.29\%), respectively. Invited entrepreneurs suggested improving label on the cup, so it will become more attractive. According to the entrepreneurs, students need to create a uniqueness of this product. They also suggested to more careful on the raw materials quality, since it is a perishable material especially during handling and storage.

\section{Production of Soycorn milk with capacity of 10 L/day}

Soycorn milk is a nutritious healthy beverage. It contains protein, carotenoids, sugars and minerals. It also contains isoflavones which act as antioxidant. It has wide market share from chil- 
dren to elderly people. The non-complicated processing is also a reason to produce the product. They produced the soycorn milk by extracting a blend of boiled soybean and steamed sweet corn, then filtering, mixing with sugar, heating up to $65 \mathrm{oC}$, adding stabilizer (xantan gum), pasteurization (70oC, 15 minutes), bottling (hot filling @330 mL) and labeling. Total production cost, income and profit were IDR 389,000; IDR 570,000; and IDR 181,000 (46.47\%), respectively. Invited entrepreneurs provide a positive comment to the product created by this group. It was a new product in beverage market. They suggested to more careful on production and selling management since the product has a short shelf life about 3 days in refrigeration.

\section{Production of Bumble bee with capacity of 10 L/day}

Bumble bee was formulated by using honey, water and agars. Honey contains sugars (glucose and fructose), minerals, enzymes and phytochemicals depend on the flower type. Health effect of honey is antioxidant, antimicrobes and tonic. The product was served as a fresh drink in cup of $350 \mathrm{~mL}$. Total production cost, income and deficit were IDR 454,000; IDR 324,000; and IDR 130,000 (28.63\%), respectively. This group is just one only group suffered losses. In evaluation forum, invited entrepreneurs provide a positive comment to the product created by this group. They suggested to more careful on the raw materials and ingredient purchasing. They purchase the honey with too expensive price. They also suggested to do not purchase in retail, but in agent or supplier.

\section{Self-confidence of students in entrepreneurship}

Figure 1 show percentage of students who possess sufficient self-confidence (score of 6 and above) to success as an entrepreneur, financing aspect, managerial skill aspect, business planning aspect and marketing aspect. Percentage of student who possess sufficient selfconfidence (score of 6 and above) were increase in all aspects measured. Most of student possesses sufficient self-confidence to success as an entrepreneur. After implementation of the teaching process, there are no significance changes in that parameter (from $83.33 \%$ to $84.85 \%)$. The significance increasing of number of students who possess sufficient self-confidence was occurred in financing (from $60.61 \%$ to $68.18 \%$ ), managerial skill $(71.21 \%$ to $75.76 \%$ ), business planning (from $66.67 \%$ to $75.76 \%$ ) and marketing aspects $(68.18 \%$ to $78.79 \%)$. That data indicated that the project implementation is suitable to improve entrepreneurial intention in the course especially in business planning and marketing.

Figure 2 show the changes (increase, constant and decrease) of student self-confidence score after the implementation of the teaching process. Significant increasing of self-confidence score to success in business planning and marketing occurred. However, declining of self-confidence in financing, and managerial skill aspects occurred. This might be caused by they do not have a sufficient knowledge and skill of financing and managerial. It is needed to improve self-confidence in investment and finance, and managerial skill aspects.

\section{CONCLUSIONS}

Business planning project with experiential learning in beverage processing technology course have been successfully implemented. The project improved students self-confident 
to success as an entrepreneur, especially in business planning and marketing aspects. It is needed to improve the student self-confidence in managerial skill and financing aspects.

\section{BIOGRAPHY}

\section{Ignatius srianta}

He is lecturer in Department of Food Technology, Widya Mandala Surabaya Catholic University. He teaches beverage processing technology, food analysis and food industrial sanitation. Survey, consulting and training for school stakeholders, food industry practicists and society are also his activities. He participated in short course on soybean oil extraction and processing, Texas A\&M University, College Station, Texas, USA as part of Education for Community of Food Enterprises Development (ECFED) Program.

\section{Catharina Yayuk Trisnawati}

She is lecturer in Department of Food Technology, Widya Mandala Surabaya Catholic University. She teaches beverage processing technology, bakery technology and research methodology. Survey, consulting and training for school stakeholders, food industry practicists and society are also his activities.

\section{ACKNOWLEDGEMENT}

Thanks to Directorate General of Higher Education, Department of National Education, Republic of Indonesia for financial supporting through teaching grant of PHKI year 2010 in Widya Mandala Surabaya Catholic University with contract number of 224/PHKI/UKWMS/2010.

\section{REFERENCES}

Azizi, B., Hosseini, J.F., Hosseini, M. and
Mirdamadi. 2010. "Factors influencing the development of entrepreneurial education in Iran's applied-scientific educational centers for agriculture". American Journal of Agricultural and Biological Sciences 5(1): 77-83.

Bosma, N., Acs, Z.J., Autio, E., Coduras, A. and Levie, J. 2009. 2008 Executive Report. Global Entrepreneurship Monitor.

Co, M.J. and Mitchell, B.(2006). "Entrepreneurship education in South Africa: a nationwide survey". Education + Training 48(5): 348-359.

Frazier, B.J. (2005). "Teaching entrepreneurship to non-business majors: a constructivist learning approach". United States Association for Small Business and Entrepreneurship (USASBE) 2005 Conference Proceedings.

Honig, B. (2004). "Entrepreuneurship education: toward a model of contingency-based business planning". Academy of Management Learning and Education 3(3): 258-273.

Hamidi, D.Y., Wennberg, K. and Berglund, H. (2006). "Creativity in entrepreneurship education". Journal of Small Business and Enterprise Development 15(2): 304-320.

Indarti, N. and Rostiani, R. (2008). "Intensi kewirausahaan mahasiswa: studi perbandingan antara Indonesia, Jepang dan Norwegia". Journal of Indonesian Economy and Business 23(4).

Koster, S. and Rai, S.K. (2008). "Entrepreneurship and economic development in a developing country: a case study of India". Journal of Entrepreneurship 17(2): 117-137.

Lumsdaine, E and Binks, M. (2003). Teaching entrepreneurship to engineers. In Proceeding of the 2003 American Society for Engineering Education Annual Conference and Exposition, session 3554.

Tambunan, T. (2009). "Women entrepreneurship in Asian developing countries: their development and main constraints". Journal of Development and Agricultural Economics 1(2): 027-040.

Yusof, M. and Jain, K.K. (2010). “Categories of university-level entrepreneurship: a literature survey". Int Entrep Manag J 6:81-96. 


\section{Table 1 Student characteristics}

\begin{tabular}{|c|c|}
\hline Characteristics & $\begin{array}{l}\text { Number of student } \\
\text { (Per cent) }\end{array}$ \\
\hline \multicolumn{2}{|l|}{ Gender } \\
\hline -male & $17(23.94 \%)$ \\
\hline -female & $54(76.06 \%)$ \\
\hline Age & 20-21 years old \\
\hline \multicolumn{2}{|l|}{ Parent occupation } \\
\hline -government employee & $4(5.60 \%)$ \\
\hline -entrepreneur & $44(61.97 \%)$ \\
\hline -private sector employee & $22(30.99 \%)$ \\
\hline -others & $1(1.41 \%)$ \\
\hline \multicolumn{2}{|l|}{ Student activity } \\
\hline -studying & $47(61.04 \%)$ \\
\hline -studying and working in the company & $0(0.00 \%)$ \\
\hline -studying and working in the business of parents & $6(8.45 \%)$ \\
\hline -studying and working independently & $18(25.35 \%)$ \\
\hline \multicolumn{2}{|l|}{ Career planning in the future } \\
\hline -government/private sector employee & $6(8.45 \%)$ \\
\hline -continuing parent's business & $1(1.41 \%)$ \\
\hline -entrepreneur & $10(14.08 \%)$ \\
\hline -continuing study & $4(5.60 \%)$ \\
\hline $\begin{array}{l}\text {-working in private sector for several years, then will build a new } \\
\text { venture }\end{array}$ & $50(70.42 \%)$ \\
\hline
\end{tabular}


Figure 1 Percentage of students who possess sufficient self-confidence to success as an entrepreneur (score of 6 and above) before and after implementation the project

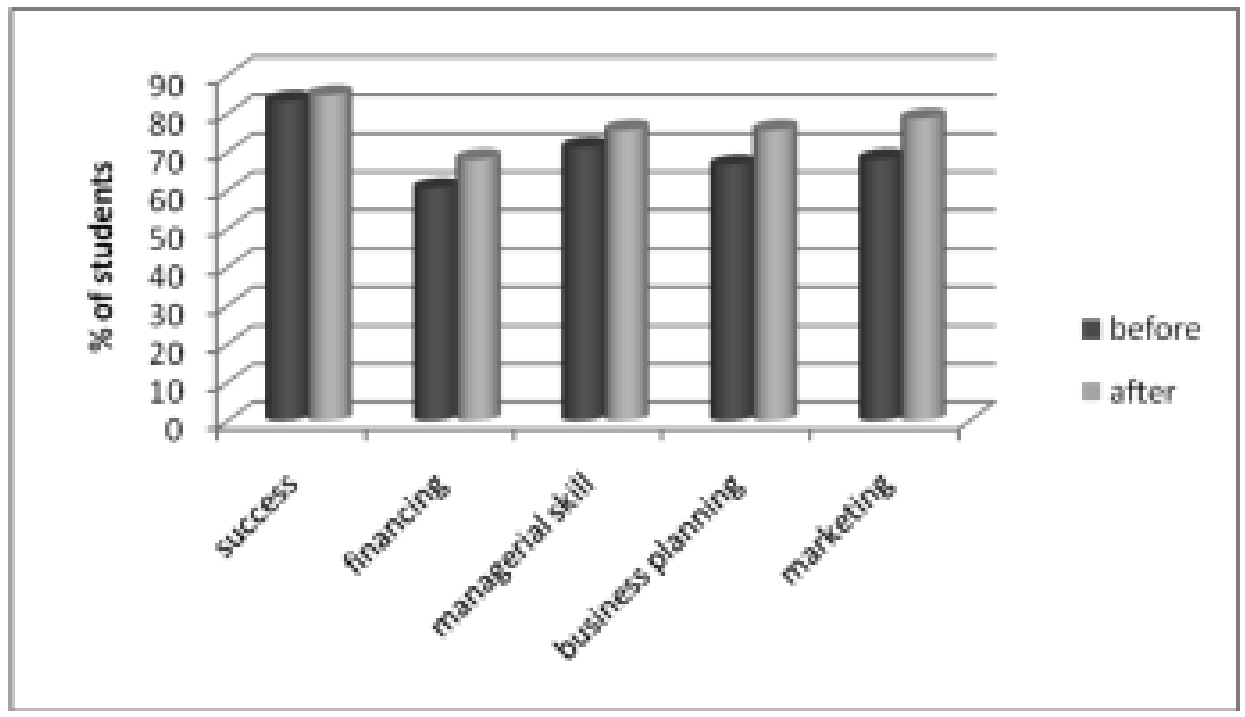

Figure 2 Changes of student self-confidence after implementation the project

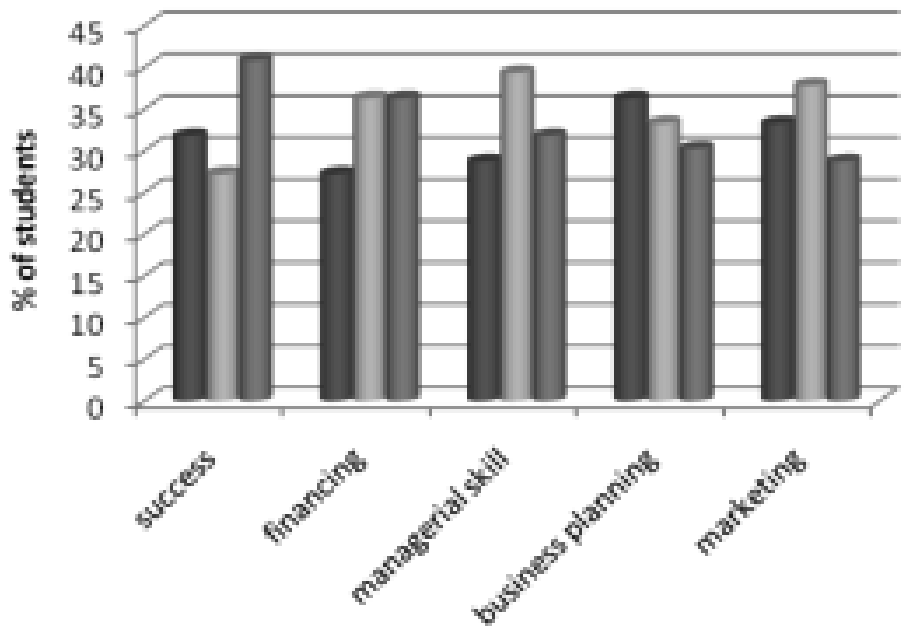

- increase

E constant decrease 